Open Access

\title{
Public space design of knowledge and innovation spaces: learnings from Kelvin Grove Urban Village, Brisbane
}

\author{
Surabhi Pancholi ${ }^{1}$, Tan Yigitcanlar ${ }^{1 *}$ and Mirko Guaralda ${ }^{2}$
}

\author{
* Correspondence: \\ tan.yigitcanlar@qut.edu.au \\ ${ }^{1}$ School of Civil Engineering and \\ Built Environment, Queensland \\ University of Technology, 2 George \\ Street, Brisbane, QLD 4001, Australia \\ Full list of author information is \\ available at the end of the article
}

\begin{abstract}
The era of knowledge-based urban development has led to an unprecedented increase in mobility of people and the subsequent growth in new typologies of agglomerated enclaves of knowledge such as knowledge and innovation spaces. Within this context, a new role has been assigned to contemporary public spaces to attract and retain the mobile knowledge workforce by creating a sense of place. This paper investigates place making in the globalized knowledge economy, which develops a sense of permanence spatio-temporally to knowledge workers displaying a set of particular characteristics and simultaneously is process-dependent getting developed by the internal and external flows and contributing substantially in the development of the broader context it stands in relation with. The paper reviews the literature and highlights observations from Kelvin Grove Urban Village, located in Australia's new world city Brisbane, to understand the application of urban design as a vehicle to create and sustain place making in knowledge and innovation spaces. This research seeks to analyze the modified permeable typology of public spaces that makes knowledge and innovation spaces more viable and adaptive as per the changing needs of the contemporary globalized knowledge society.
\end{abstract}

Keywords: Knowledge and innovation space; Place making; Contemporary public spaces; Knowledge-based urban development; Knowledge worker; Kelvin Grove Urban Village; Brisbane: Australia

\section{Background}

Public spaces are at the heart of democratic living (Carr et al. 1992), they are the main stage of urban life and facilitate encounters, exchange of experiences and foster a tolerant urban society through the exposure to different people and their traditions (Worpole \& Greenhalgh 1996). These spaces are constantly charged with symbols and meanings that enhance the identity of a society (Zukin 1995). Different disciplines have different definition of what is a public space, highlighting for example land tenure, accessibility or social interaction. This research focuses on public spaces and their important role in the creation of local identity or place making (Amin \& Graham 1997; Massey 2005). Policymakers more and more acknowledge the importance of place globally (Yigitcanlar et al. 2007; Van Winden 2010).

The concept of place had been defined in different ways (Arefi 2004), but it is generally recognized that place making is a process depending on people's experience of a locale. 
Design plays a central role in characterizing and defining this experience (Buttimer 1980). Places do not just exist; they are the product of a society and embed different level of symbolism (Cresswell 2004). An understanding of the socio-cultural context of a locale is considered one of the factors to achieve effective place making through design (Massey 2005). Scholars, such as Carmona et al. (2010), support the idea that urban design can be implemented as a process of facilitating a sense of place for a specific context. Urban design emphasizes the importance of people and place (Adams \& Tiesdell 2013), but it is also a process affected by globalized forces, market and regulatory factors (Kabachanik 2010). For instance, Carmona et al. (2010) asserts that urban design can be considered to involve direct and indirect design factors that shape the nature of a place through establishing policy, making investment decisions and managing space. Public spaces, thus, include both physical and the social dimensions (Duff 2010). Shaftoe (2008) indicates that production of successful public spaces involves an integrated approach with a proper interplay of design and management within the broader context of urban policies. Worpole (2005) observes that design alone cannot solve the problems being placed into the deep social and economic nature of circumstances that undermine a vibrant community and public space culture. Hence, it is necessary to take an integrated approach to understand place making in contemporary public spaces, especially in contexts that are specifically designed with the intention of providing a unique experience to a particular social group (Watson \& Bentley 2007).

This study considers place making in public spaces within the context of knowledgebased urban development (KBUD). During the last few decades, KBUD has been at the center of policymaking in many global or world cities that seek to attain long-term competitiveness (Yigitcanlar 2009; Lonnqvist et al. 2014; Yigitcanlar \& Bulu 2015). Globally the acceptance of KBUD as the panacea for all the social, economic, environmental and spatial challenges being faced by contemporary development (Knight 1995; Kunzmann 2009; Yigitcanlar 2010; Yigitcanlar \& Sarimin 2015) has manifested into the consequent emergence of new typology of knowledge milieus in the form of knowledge and innovation spaces (KISs) (Asheim 2007; Inkinen 2015). Few global successful examples include, but not limited to Silicon Valley, Silicon Alley in New York, Silicon Roundabout in London, Ørestad in Copenhagen, Brainport in Eindhoven, One-north in Singapore, Australian Technology Park in Sydney, Parkville Knowledge Precinct in Melbourne, and Kelvin Grove Urban Village (KGUV) in Brisbane (Carrillo et al. 2014). One of the major objectives of KISs is to attract and retain skilled human capital in the form of knowledge workers by providing them with quality of life in ultimately unique places (Yigitcanlar et al. 2007; Florida 2012). Place making plays a major role in retaining talent, as considerations about the quality and character of place are essential components of KBUD policies (Pratt 2002; Sheppard, 2002). Nevertheless, accommodating and absorbing the flows and processes of globalization-i.e., diversity of populatio$\mathrm{n}$-and retaining these people is a significant challenge for cities. Knowledge workers, an emergent class, have special needs and requirements (Zenker 2009). More importantly, with the acceptance of open innovation model as the key to success in global economy, these traditionally secluded KISs are transfiguring themselves as more extrovert and accessible locations (Chesbrough 2003; Kodama \& Shibata 2015). Additionally, one of the major objectives of KBUD, in sync with the global climate change awareness, is sustainable enviro-urban development (Yigitcanlar \& Lonnqvist 2013; 
Cooke 2015; Yigitcanlar et al. 2015a). These needs and requirements are impacting on the formation of new typologies of settlements and public spaces within KISs.

This gives rise to the following question: What is the role and characteristics of public spaces to facilitate place making in contemporary KISs? In order to provide answers to this question, a case study investigation is undertaken in one of the most consolidated KISs' of Brisbane-the capital city of Queensland in Australia. Australia is one of the rapidly growing knowledge economies globally (Yigitcanlar et al. 2008a) and Brisbane is one of the emerging knowledge centers in the country (Yigitcanlar \& Velibeyoglu 2008). Several Australian cities have been witnessing a similar trajectory of development, where KBUD have been implemented as key components of strategic developments. Renowned other examples of this process are Melbourne and Sydney (Yigitcanlar 2010).

The overall aim of the paper is to contribute to the existing understanding of place making in the context of emerging KISs' public spaces. To do so, we seek to develop an understanding of the major attributes that have been attached to the public spaces in these new emerging typologies aiming to achieve a thriving KBUD. The paper, first, reviews the literature about the special conditions of KBUD, and the profile of knowledge workers, which sets the broader context for the case study. The paper identifies the attributes that make KISs viable, vibrant and capable of attracting and retaining global knowledge workers. KGUV is, then, evaluated taking in consideration of which design strategies have been implemented to develop a unique sense of place in this KIS. The study attempts to understand in what ways different attributes have been implemented in the design of this contemporary KIS.

\section{Contemporary public space design in Kelvin Grove Urban Village}

KGUV is a sustainable urban community developed as an integrated and masterplanned urban village within a mixed-use and highly urban environment (Brisbane City Plan 2000; Yigitcanlar et al. 2015b). This Queensland Government's flagship urban renewal project is developed as a joint initiative by Queensland University of Technology (QUT) and Queensland Government Department of Housing, only 2 kilometers from Brisbane's CBD. One of the major prestigious awards won by this development is the Planning Institute of Australia's 'National Design Excellence Award' in 2004 (Yigitcanlar \& Dur 2013). Acknowledged as a landmark project of KBUD in Brisbane and a design that aims at creating strong sense of place and community in a safe environment, the case gives an opportunity to explore the characteristics of public spaces in the context of KBUD (Foth \& Adkinsor 2006; Foth et al. 2008; Yigitcanlar et al. 2008b; Klaebe et al. 2009). The methodology of the study is two-fold. First, we undertake a concise review of the literature to set the 'broader context'. Then, we undertake 'site observations' to reveal insights from the case of KGUV.

\section{Broader context}

KIS is considered as the 'spatial nexus' for the generation and dissemination of knowledge in knowledge-based economic development and KBUD (Yigitcanlar et al. 2008b; Sabatini-Marques et al. 2015). Yigitcanlar and Lonnqvist (2013) summarize KBUD as a policy that targets of building a 'place' to form perfect climates not only for business, but also for people, place, governance and their integration. Thus, these four 
developmental perspectives establish the four main pillars of KBUD-i.e., economy, society, environment and governance (Yigitcanlar \& Sarimin 2011; Yigitcanlar 2014). Brisbane is one of the emerging knowledge cities of Australia (Yigitcanlar et al. 2008a); policies such as the 'Smart State Strategy' developed by the Queensland Government, or the 'Smart City Strategy' for Brisbane had a considerable impact over the spatial restructuring of this city. These projects, concentrated on the social and urban development policy areas in order to establish the city in a global knowledge economy by producing an investment-friendly business climate as well as enhancing the endogenous skill set of the residents (Wiltshire 2003). They shifted the economic base from traditional industries to knowledge sectors (Mort \& Roan 2003), thus, transitioning the modest local economic development policy to the more ambitious KBUD perspective. The pentagon prism model that forms the base of the Smart City Strategy deals with five aspects: creative, administrative, business, natural and built environments, with connectivity playing a crucial role in strengthening local and global linkages (Yigitcanlar \& Velibeyoglu 2008). These KISs, generally clustered together, are spatially characterized by the presence of blurred boundaries between the spaces of live-work-play-learn-cyber (Yigitcanlar 2010). The strong foundation of Brisbane in a number of knowledge industry sectors such as biotechnology and biosciences, aviation and aerospace, and information technology has fuelled the development of KISs in and around the city (Yigitcanlar \& Velibeyoglu 2008), such as KGUV, Da Vinci Airport Precinct, information technology sector in Milton, CBD and Fortitude Valley (also hosting the entertainment sector), Boggo Road Urban Village and Knowledge-based Research and Business Precinct and Dutton Park, on the Southside Nathan with Griffith University campus, Mt Gravatt Research Park and Brisbane Technology Park, Griffith University on the Gold Coast, on the north side University of the Sunshine Coast Knowledge Town and so on. A few of these locations are in the developmental stage and others are already fullyfledged and functional (Yigitcanlar et al. 2015b).

Creative Class Thesis of Florida (2002), which is based on the idea of the 3T's-i.e., technology, talent and tolerance-is at the center of these types of development. Florida's thesis asserts the central importance of knowledge workers in the contribution to global knowledge economy (Baum et al. 2009). With about $21 \%$ of Brisbane's population being young people, special attention is being given by policymakers to knowledge workers as is evident in the recent formulation of the Youth Strategy 2014-2019 aiming at making youth engaged, empowered, valued and celebrated. These modern age workers possess a few characteristics that make them distinct (Zenker 2009). They are well informed and participative; seek a better quality of life; culturally active and artistically expressive; displaying diversity and tolerance; having high competency in human social interactions (Carrillo 2004). The objectives attached with the public spaces in KISs, therefore, are getting reconfigured with their changing preferences and progressive sense getting attached to place making in KISs with globalization (Pancholi et al. 2014). It needs to be noted that progressive sense of place is a concept based on the wider world integration of a locale in the local and global contexts; this process enriches itself by the merging of all flows and processes (Massey 1991; Lippard 1997). Hence the definition of place making in contemporary public spaces, that we are referring here, is based on the idea of developing 'permanence' from the flow of 'processes' (Cresswell 2004). We, hence, define place as a: (i) Spatio-temporal entity dependent on uniqueness of location, and; (ii) Process dependent on flows. 
At large, Carr et al. (1992) list the following characteristics of good public spaces: they should be meaningful, democratic (in accessibility, expression and rights), responsive, comforting, engaging (passively and actively), and provide a sense of discovery. Historically, KIS developments were constructed as secluded campuses with an introvert character as required for research-oriented environment. In many of the older version of KISs, i.e., science and industrial parks, the use of public spaces was majorly limited to relaxation and engagement of internal users. With growing extroversion of such spaces, Yigitcanlar et al. (2008b) summarize the holistic objective of modern KISs as not only purely generation, but also transfer and transmission of knowledge for socioeconomic growth of cities and their regions (Yigitcanlar et al. 2008b); therefore, attaching a new purpose to public spaces of modern KISs along with the abovementioned characteristics outlined by Carr et al. (1992). Contemporary public spaces in KISs are not only required to be serving as entertaining, relaxing, comforting and engaging points, but also as a place that acts as the first point of connection between the knowledge space and the city, allowing the maximum knowledge dissemination within its boundaries and as well as outside the boundaries. This leads us to two major objectives for contemporary public spaces to facilitate place making in KISs: (i) Developing a sense of meaning and attachment, i.e., by attracting and retaining knowledge workers within KISs by providing them a sense of permanence in a unique 'place' that is developed by being contextual, connected, sustainable and vibrant internally, and; (ii) Facilitating the external flow and processes of knowledge, i.e., by being responsive towards the broader context, connected by an active relationship of give-and-take between the KIS and the city, the region and also at the global levels keeping it viable, vibrant, resilient and adaptable. These characteristics are further explored in the case of diverse and globalized KBUD community of KGUV.

\section{Site observations}

For the case investigation, we applied a simple but effective analytical framework that is dependent on two major attributes derived from the aforesaid definition of place making. These are: (i) 'Character', i.e., arising from culture, scale, climate and environment, and; (ii) 'Connectedness', i.e., harder layers, such as spatial and visual elements, or softer ones, such as socio-cultural milieu. The specific character serves as the context for the creation of a sense of place; connectedness acts as the catalyst in developing and maintaining a specific identity. In the case examined, this is achieved by being context-sensitive and humanscaled. This approach provides a sense of familiarity to the newly arrived population that is able to relate to the local culture, heritage and natural context. On the other hand, connectedness with the outer world is necessary for the dissemination of knowledge. Connectedness integrates the KIS with its surroundings and wider context, thus, contributing not only in knowledge dissemination, but also in regional development. KGUV case study is analyzed at two levels: (i) Development of sense of meaning and permanence is investigated within the KIS and externally, and; (ii) Progressive place to facilitate external and internal flows is being analyzed at the KIS and city or global levels, considering the give-and-take process at a broader scale. Each of these major attributes is further divided into sub-attributes. Sitespecific character is analyzed under the sub-attributes of context integration and peopleorientedness, while character at broader scale is analyzed under creative image and role of 
wider climate and global image on built character. On the contrary, connectedness of public spaces is analyzed internally and externally at spatial, visual and socio-cultural level.

KGUV is a well-established inner city suburb and an example of an award-winning knowledge community. KGUV is a result of advanced planning processes that has produced a master plan document defining specific codes for the design of individual buildings (Figs. 1 and 2). Master plan and the development are based on the triplehelix model-i.e., a joint venture between university, public and private sectors-and provided public spaces with unique character. This intervention is centered on creative industries and biosciences; QUT is the most recognizable presence in the precinct, which is promoted for its creative and vibrant village atmosphere providing a highly urban and well-integrated live-work-play-learn environment. KGUV applies some recognizable principles in its design that are commonly suggested as key factor in the establishment of a KISs (Yigitcanlar et al. 2008b; Yigitcanlar \& Dur 2013). The salient design characteristics are listed and briefly elaborated below:

- Mixed land uses: KISs are characterized by the presence of mixed-uses that contributes to their vitality and economic diversity (Charles 2011). This is evident in KGUV (Fig. 1).

- Contemporary high-tech environment: Spaces that generate knowledge should reflect the innovation and creativity by their contemporary high-tech environment. The use of modern materials in built form, integration of high-tech elements in public spaces, and strong digital connections are few of such initiatives as evident in the case considered.

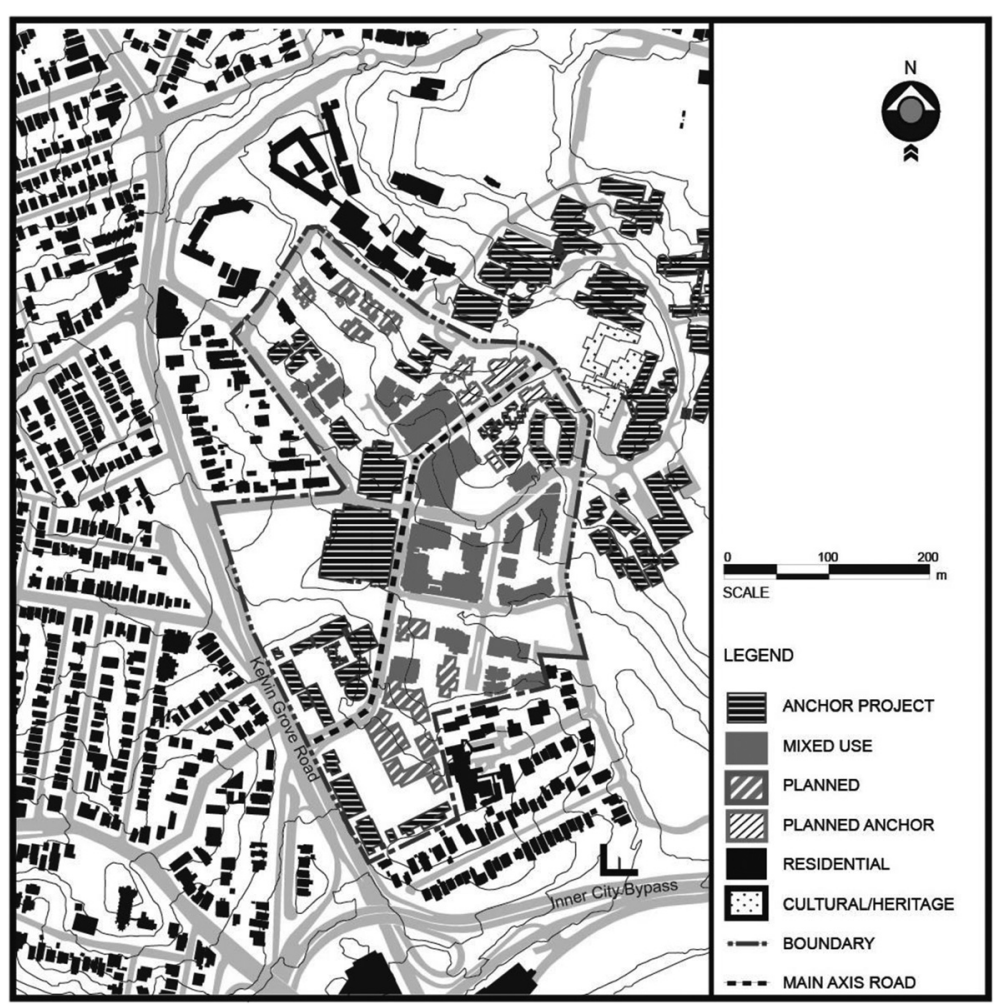

Fig. 1 Figure ground map of KGUV 


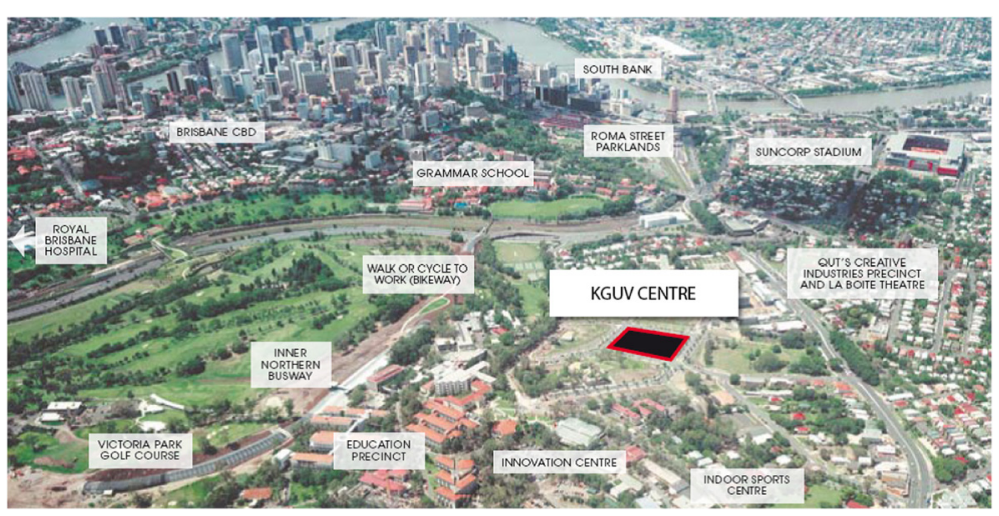

Fig. 2 Location and vicinity of the urban village

- Anchor project dominancy: KISs are characterized by the existence of one main building and complex as anchor project that provides character and flavor to the area, and also acts as base support for all ancillary activities. In KGUV, QUT is the main anchor project (Fig. 1).

- Presence of an axis: In Brisbane's KISs, one main street leading to the anchor project acts as major axis or public spine. This boulevard acts as the major spine of KGUV with the entire main commercial, institutional and public activities distributed around it, e.g., Musk Avenue in KGUV (Fig. 3).

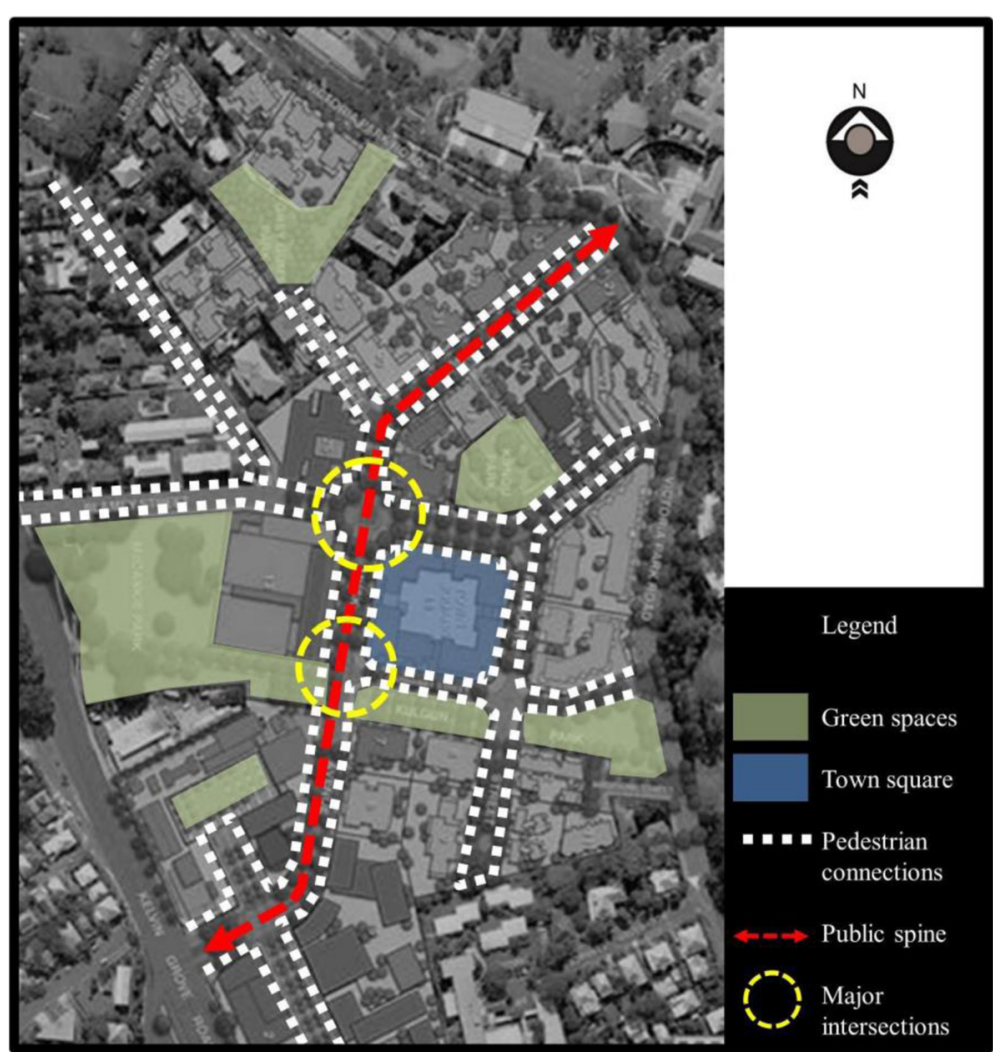

Fig. 3 Interconnectivity of public spaces (derived from Brisbane City Plan, 2000) 
- Compact development: Contemporary KISs are mostly getting developed as compact development. With a concentration on variety of housing typologies catering to the diverse population and ranging from medium to high density, KGUV is also developed to have a dense and compact built-form. The residential development is mostly in the form of multi-unit dwellings and apartments.

- Central public and open spaces: The public and open spaces including the town center are given central location in KGUV (Fig. 3).

The analysis of planning documents (Brisbane City Plan 2000) and site observations support the understanding on how place making strategies have been integrated in the overall design of KGUV. The findings of these analyses, including major public space features, are presented below under a categorical classification, and also summarized in Table 1 .

Table 1 Summary of major public space features in KGUV

\begin{tabular}{|c|c|c|c|}
\hline Place level & $\begin{array}{l}\text { Derived } \\
\text { attributes }\end{array}$ & $\begin{array}{l}\text { Attributes } \\
\text { addressed }\end{array}$ & Description \\
\hline \multirow[t]{8}{*}{$\begin{array}{l}\text { SITE-SPECIFIC } \\
\text { SCALE }\end{array}$} & \multirow[t]{4}{*}{ Character } & \multirow[t]{2}{*}{ Context integration } & $\begin{array}{l}\text { Integration of historical military context, } \\
\text { indigenous Turrubal community and native } \\
\text { residents in built form, parks' and streets' names. }\end{array}$ \\
\hline & & & $\begin{array}{l}\text { Integration of nature by retaining native old } \\
\text { trees in the McCaskie Park. }\end{array}$ \\
\hline & & \multirow[t]{2}{*}{$\begin{array}{l}\text { People- } \\
\text { orientedness }\end{array}$} & $\begin{array}{l}\text { Human scale, buildings up to seven stories high } \\
\text { and use of human scale elements at front entrances. }\end{array}$ \\
\hline & & & $\begin{array}{l}\text { Pedestrian friendly streetscape by high level of } \\
\text { detailing in pavements, street furniture, use of } \\
\text { artworks, and landscaping. }\end{array}$ \\
\hline & \multirow[t]{4}{*}{ Connectedness } & \multirow[t]{2}{*}{ Spatial connectivity } & $\begin{array}{l}\text { Interconnected open space network by continuous } \\
\text { pathways. }\end{array}$ \\
\hline & & & $\begin{array}{l}\text { Seamless integration of main project with built } \\
\text { environment. }\end{array}$ \\
\hline & & \multirow[t]{2}{*}{$\begin{array}{l}\text { Visual and socio- } \\
\text { cultural connectivity }\end{array}$} & $\begin{array}{l}\text { Concept of 'eyes-on-street' by houses overlooking } \\
\text { the public spaces. }\end{array}$ \\
\hline & & & $\begin{array}{l}\text { Accessibility of public to all display areas of the } \\
\text { university (i.e., QUT). }\end{array}$ \\
\hline \multirow[t]{8}{*}{ BROADER SCALE } & \multirow[t]{4}{*}{ Character } & \multirow[t]{2}{*}{ Creative image } & $\begin{array}{l}\text { Transparent facades of the lower floors, where } \\
\text { creative arts are displayed engage the outsiders. }\end{array}$ \\
\hline & & & $\begin{array}{l}\text { Use of public art reflects the creative context of } \\
\text { creative industries. }\end{array}$ \\
\hline & & \multirow[t]{2}{*}{ Built character } & $\begin{array}{l}\text { High-tech built environment based on knowledge } \\
\text { and urban lifestyle that gives a global KIS character. }\end{array}$ \\
\hline & & & $\begin{array}{l}\text { Implementation of climate-responsive subtropical } \\
\text { design principles. }\end{array}$ \\
\hline & \multirow[t]{4}{*}{ Connectedness } & \multirow[t]{2}{*}{ Spatial connectivity } & $\begin{array}{l}\text { Considerable integration with surrounding } \\
\text { neighbourhoods. }\end{array}$ \\
\hline & & & $\begin{array}{l}\text { Well connected by transport to other parts of city, } \\
\text { but a less permeable boundary. }\end{array}$ \\
\hline & & \multirow[t]{2}{*}{$\begin{array}{l}\text { Visual and socio- } \\
\text { cultural connectivity }\end{array}$} & $\begin{array}{l}\text { Remarkable CBD and mountain panorama from the } \\
\text { residences and offices. }\end{array}$ \\
\hline & & & $\begin{array}{l}\text { Local markets attract visitors from other parts of the } \\
\text { city, however the site lacks of large-scale national } \\
\text { and international cultural events. }\end{array}$ \\
\hline
\end{tabular}


1. Character:

1.1. Site-specific scale:

a. Context integration:

- Integration of culture: The area has a rich military and indigenous history. Army barracks are retained as heritage and revitalized. To reflect the indigenous 'Turrbal' community's strong relationship with the land, parks and public arts are named accordingly. Besides, some of the streets are named after former eminent residents of the city to recognize their contributions to the society (Klaebe 2006).

- Integration of nature: The old native trees are conserved, including the ones in McCaskie, Grey Gums and Kulgun Parks, and large active and passive green spaces are developed (Fig. 4).

b. People-orientedness:

- Human-scale: Height of the buildings is restricted to seven stories. Urban form is planned to directly relating to human scale with a control on building heights and the use of inviting elements like awnings, podiums and sitting areas as part of the front entrances on pathways.

- Pedestrian environment: Considered as a key KIS feature extensive pedestrian areas and networks are planned. The provision of casual seating, landscaping, and integration of arts on the main axis make the environment conducive for pedestrian activities (Figs. 5 and 6).

1.2. Broader scale:

a. Creative image:

- Engaging lower floors: Buildings relate directly to public space through the planning of commercial activities and use of transparent façades, mainly in anchor projects as well as other public buildings. An example is the presence of art gallery having a transparent façade at the ground floor of

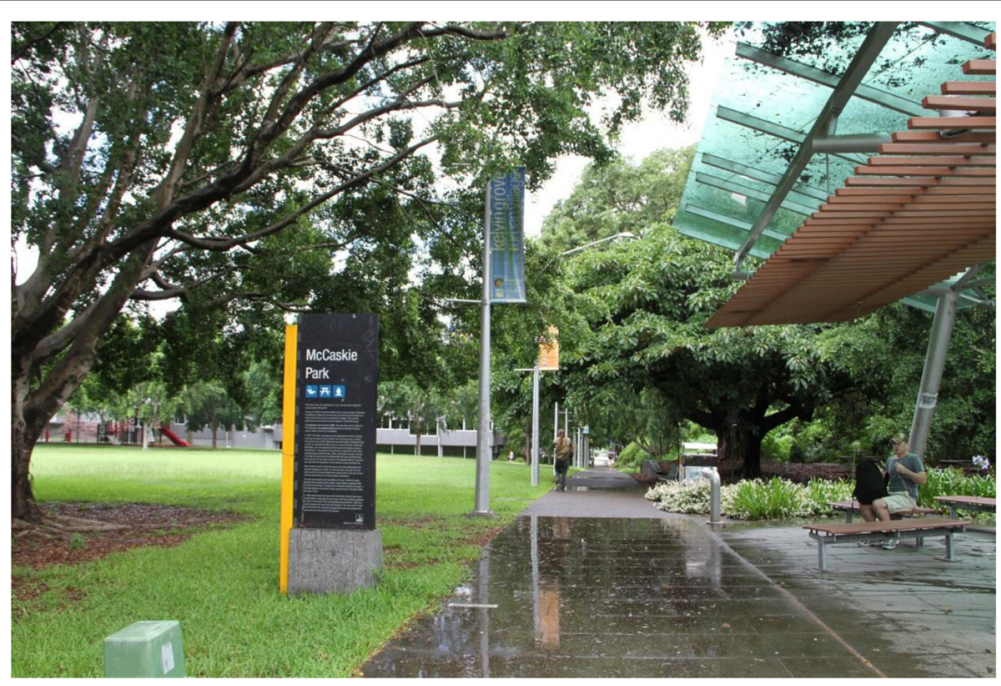

Fig. 4 McCaskie Park 


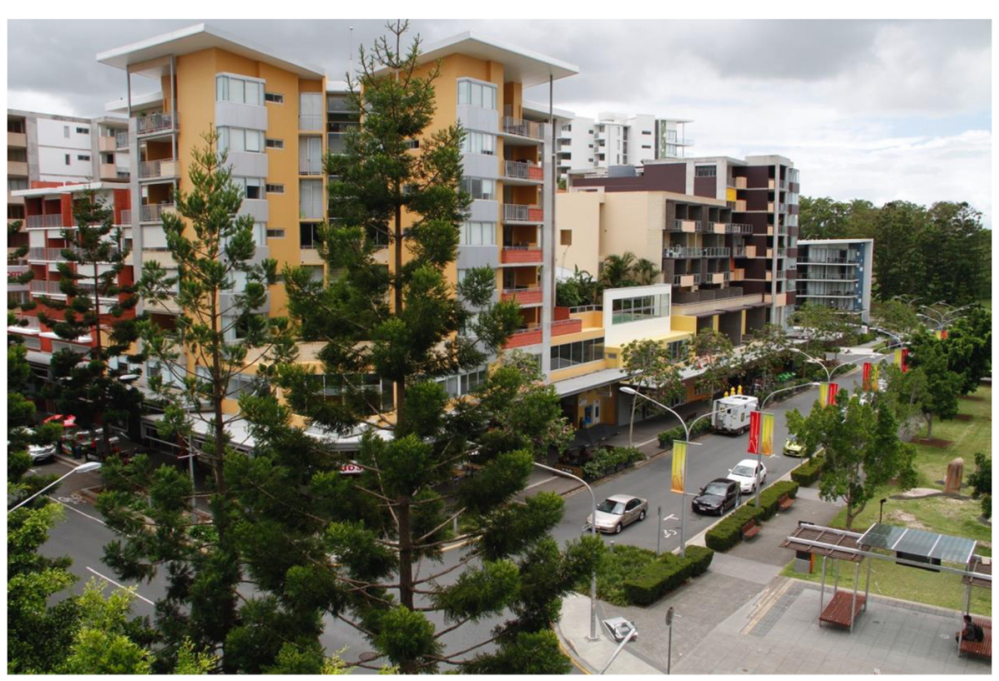

Fig. 5 Mixed-use development and public spaces

creative industries precinct. This acts as showcase of creativity related activities that take place inside the buildings and sending an extrovert image and open character of contemporary KISs, and also engaging outsiders visually by catching their attention (Fig. 7).

- Use of public arts: By the integration of public arts in the form of sculptures and creative facades at visually prominent locations, context of creativity is further strengthened. This is helpful in attaching a creative and innovative image to the KIS (Figs. 7 and 8). It is to be noted that both of these factors not only produce an image and identity in the minds of people, but also act as contact points for knowledge transfer disseminating the fresh creative ideas externally to the rest of the city.

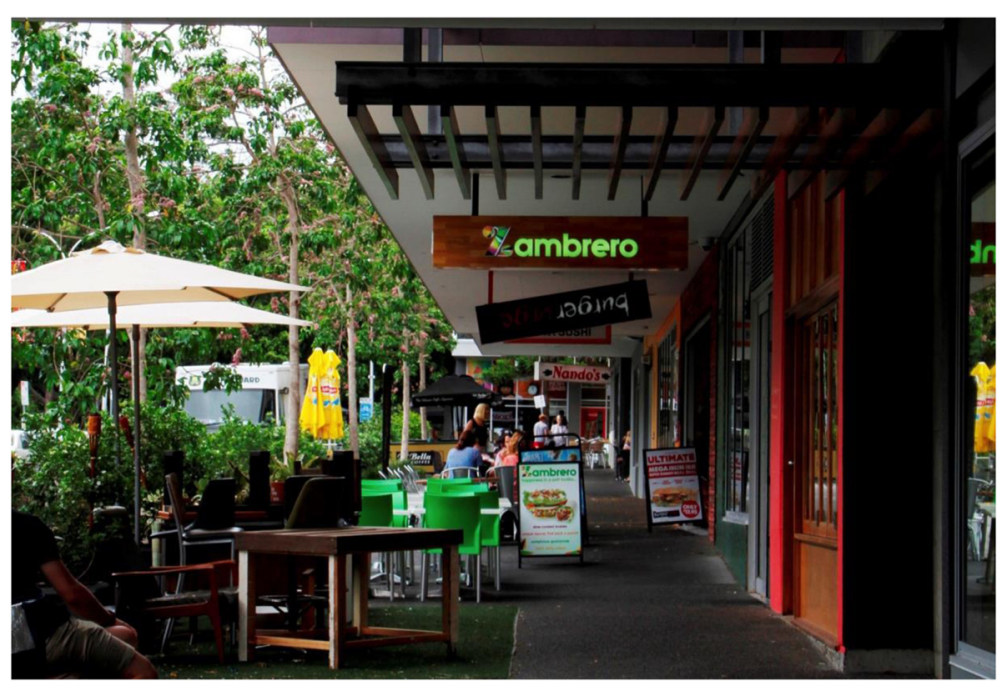

Fig. 6 Pedestrian-oriented human-scale active public spaces 


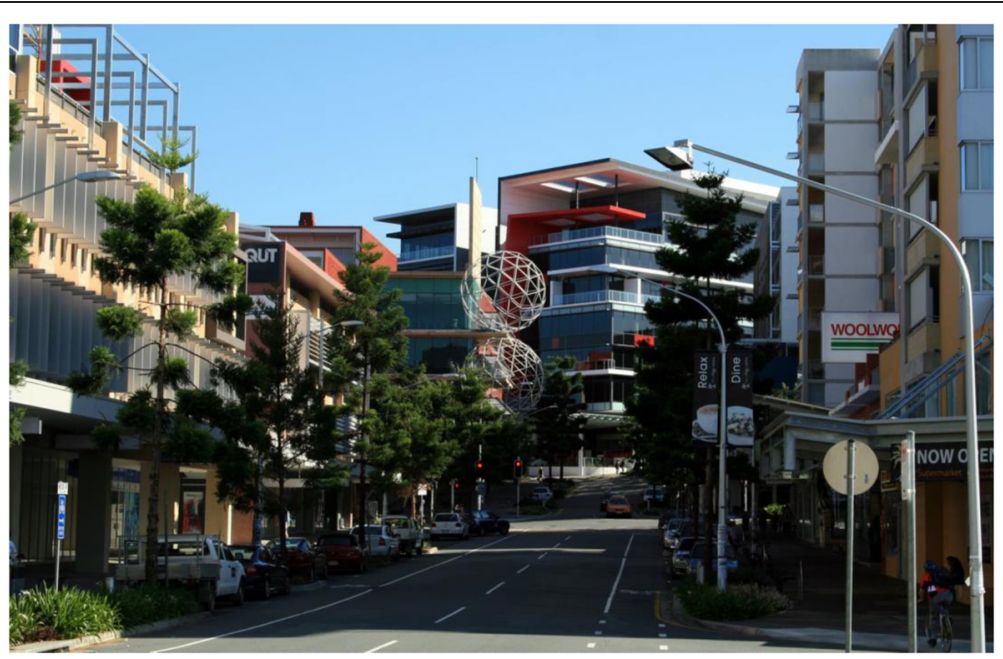

Fig. 7 Façade design and compact development

b. Built character:

- Climate-responsiveness: Considering the broader climatic context, subtropical design principles are followed throughout. Special attention has been given to develop the built form that responds to the tropical climate and include features that recall traditional elements of Queensland architecture, such as latticework, awnings and screens (Fig. 7).

- Global image: In spite of climate-sensitive design principles, the use of modern construction material in façades reflects the progressive context of 'innovation'. High-tech built environment relating to knowledge and urban lifestyle gives a global contemporary ambiance to the KIS.

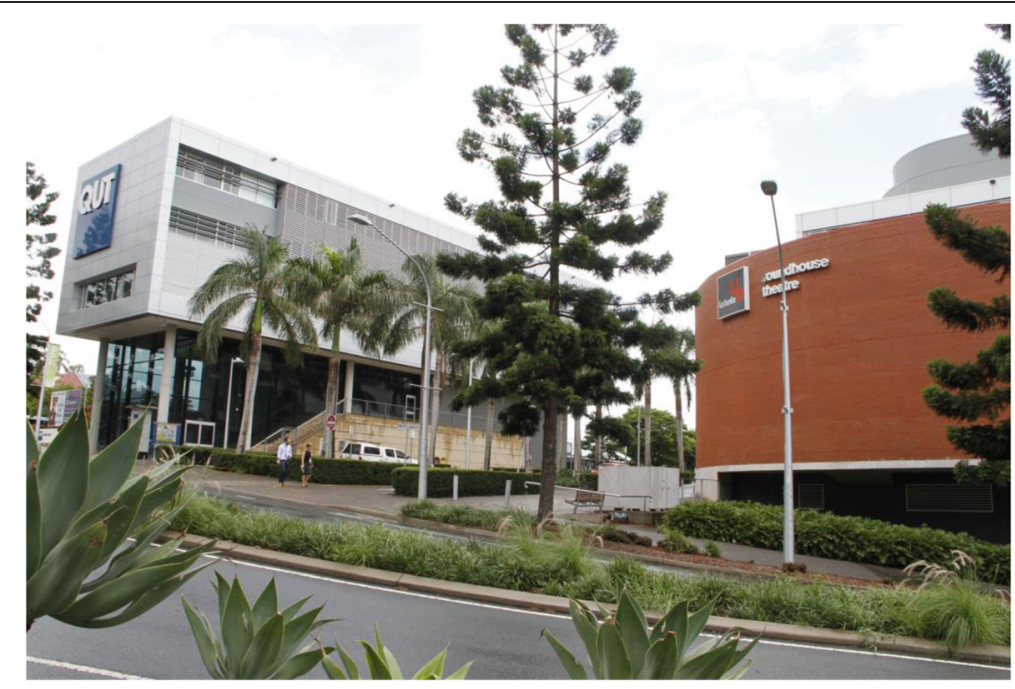

Fig. 8 QUT and La Boite Theatre 


\section{Connectedness:}

2.1. Site-specific scale:

a. Spatial level:

- Interconnected public spaces: The main axis of KGUV sets up a system of connections thus increasing the permeability within the KIS. All of the green and public spaces are connected through continuous pedestrian pathways (Figs. 2 and 7).

- Integration of anchor project: The anchor project, i.e. QUT's campus, is seamlessly integrated with the rest of the KIS, and has boundaries that are blurred (Fig. 2).

b. Visual and socio-cultural level:

- Private-public visual connections: Provision of private balconies comprising $30-75 \%$ of the length of the building façade and $30-80 \%$ of length for windows at frontage that face the main street ensures passive safety by 'eyes-on-the-street' environment, and creates visual connectivity of residents with public domain (Figs 7 and 9).

- Internal events: KGUV community has access to all display areas and organized events of the university-i.e., QUT. Additionally, the projects such as 'Sharing Stories' provide an opportunity for residents to share their experiences informally, and act in bringing the community together. Furthermore, QUT and La Boite theatre contributes to cultural liveliness of the KIS (Fig. 8).

\subsection{Broader scale:}

a. Spatial connectivity:

- Physical connections: KGUV is well connected with the city and its surroundings. Not only vehicular, but also direct pedestrian and cycle routes ensure connectivity and accessibility with the CBD. Brisbane airport is also just an 11-min' drive away, and also connected through

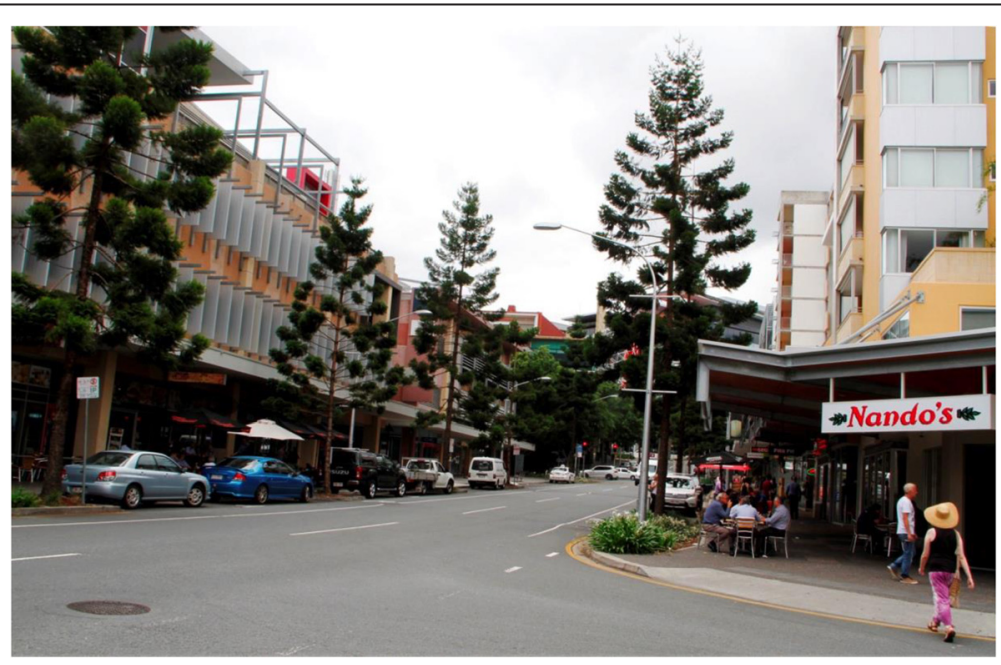

Fig. 9 Central axis, anchor project and use of climate-sensitive architectural elements 
a direct rail line. This ensures the KIS's physical linkages with the rest of the world.

- Spatial integration: The transition between the KIS and its neighborhoods is quite smooth (Minnery et al. 2009), and the development is well integrated with the surroundings (Figs. 1 and 2).

b. Visual and socio-cultural connectivity:

- Vistas: Brisbane City Plan (2000) sets a requirement for all developers to ensure the opening up of vistas of KGUV towards the CBD and mountain views. The plan also dictates the surrounding residential areas and other types of buildings to follow this rule as well.

- Events and markets: Local arts, crafts and food market are held on Saturdays, and acts as a major factor in bringing people within the KIS and surrounding suburbs together. Apart from the public events organized inside the university campus, which are accessible to all, the area still lacks the organization of a large-scale event that connects the KIS nationally and globally.

Permeability is a major attribute in facilitating the progressive sense of place making creating a sense of spatio-temporal permanence for knowledge workers in public spaces in KISs (Pancholi et al. 2014). This stands evident in the case of KGUV from the above discussion. Permeability here can be seen emerging as a key defining attribute not only in spatial, but also in social, economic and environmental terms. The defining characteristics of a permeable KIS typology for KGUV can be summated as follows:

- Spatial permeability: Spatially, this is seen in KGUV by the presence of: (i) Mixedland uses: The blurring of boundaries between the living, working and playing is one of the defining qualities of these places; (ii) Permeable urban form: Physical and visual connectivity is promoted throughout the KIS by the interconnections between public spaces and opening up of internal vistas; (iii) Permeable built forms: The façades of public and anchor project buildings are made transparent towards public domains to allow maximum visibility of activities going inside to engage people outside. The windows, entrances and also footpath uses (supported by awnings, weather-shades etc.) at lower floors enables active street frontage; (iv) External vistas: The KIS should visually connect to the outer world by opening up the vistas towards the CBD and surroundings. The spatial permeability at the broader level seems to be lacking at the level of connections with the city because of the less permeable outer layer.

- Social permeability: The social permeability in KGUV is manifested by developing:

(i) Character: Careful considerations are taken for the development of these places in a way that they respond to the original context as seen in KGUV, i.e., the revitalization of old military barracks and recognition of history of Turrbal community by integrating the aboriginal arts in public spaces and naming the parks and streets after them. This way, they communicate the local arts, culture and history to the migrant population and develop a sense of place by letting them attach meaning to the place and; (ii) Connectedness: The display of local music, arts and crafts as a part of the weekly market in KGUV is an attempt to communicate 
and share some of the local knowledge assets with knowledge workers and the public. Such markets also act as a platform for people from various cultures to display their arts, culture and music, thus giving all the social groups an equitable chance to express them. The use of ICT for providing wireless communication within the precinct also enhances the internal connectedness; (iii) Integration of diversity: Emphasis has been made on the provision of a variety of housing typologies responding to the needs of people from all social and cultural layers. However, again in the case, the social and cultural activities are not yet seen to be effectively sufficient. The enhancement is necessary to make the social layer permeable with the city and region attracting visitors from outside and disseminating the knowledge.

- Economic permeability: The economic permeability is seen at two levels in KGUV: (i) Economic ownership: A KIS unlike a traditional precinct is based on the triple helix model thus reflecting the permeability in its economic model. It is a joint collaboration between the private, public and economic sectors, and; (ii) Affordability: The permeable character is reflected in the presence of economic options for all people in such places. In KGUV a special attention is being paid to develop activities catering to all economic groups.

- Environmental permeability: A special care has been taken to blend the architecture with the context by keeping it to a scale that matches its surroundings. In case of KGUV, the low impact, medium density housing blended with the existing context is an example of connectivity with environment. Built environment needs to keep itself permeable to the wildlife and nature around. Moreover, the provision of sustainable designs stresses the integration of nature with human-made designs. Thus, a considerable extent of connectivity with between natural and man-made environment is seen in KGUV.

In sum, KGUV is succeeding as permeable typologies driven by some common underlying principles shaping it. This facilitates the flow within the confines of the space and from the space to the overall veins of the city, i.e., Brisbane. The accessibility and permeability of the area allows interactions between knowledge workers, city dwellers and occasional visitors contributing to the vibrancy of the urban village. The interaction between different social groups and the urban fabric confer to this KIS a specific character, so attaining the objective of place making for talented knowledge workers and users.

\section{Conclusions}

The research reported in this paper aimed to address the research question focuses on investigating the role and characteristics of public spaces to facilitate place making in contemporary KISs. The literature findings have shown that design of public domain within KISs is a central element in providing the vibrancy and diversity requested by the creative class of knowledge workers (e.g., Yigitcanlar \& Dur 2013; Pancholi et al. 2014). The competitiveness between global cities has generated an attention to local contexts; the specificity of locale, a unique sense of place, can provide that character and experience that young knowledge workers are looking for. In the specific case of KGUV, some constants in the design of built environment and of public spaces systems 
have been identified. The approach taken in this KIS from Brisbane is to focus on character and connectedness aspects in both site-specific and broader scales as literature indicates importance of both unique character and high connectivity and these aspects (e.g., Southworth \& Owens 1993). These aspects have influenced the planning principles in KGUV aiming to ensure a clear and legible identify for the precinct based on its creativity, heritage and its specific geographical context, for example with the introduction of subtropical design principles in the development and design of the KIS.

In terms of the key public space design and place making strategies that the master plan is implementing, the use of anchor projects, main street development and especially a layout-based on connectivity and permeability have been highlighted as KGUV's main features. These features are also present in several other KISs in South-East Queensland, for example Boggo Road Urban Village and Knowledge-based Research and Business Precinct, and the proposed Knowledge Town of Sippy Downs at the Sunshine Coast (see Yigitcanlar et al. 2015b). This is to say a local typology for KBUD is clearly emerging slowly but surely in Brisbane, which is also considering the local subtropical character that allows open space living and the traditional outdoor living of the Australian culture. In terms of the planning approach, all KISs from Brisbane have a proposed master plan that details specific codes to achieve a precise control on the quality of the built environment. Whilst the design of these developments has been recognized as successful through the award of prizes and certification, the success from the social point of view is yet to be addressed and requires a more extensive and detailed investigation. This constitutes our future research direction.

\section{Competing interests}

The authors wish to acknowledge the financial and in-kind contributions of Queensland University of Technology in supporting the research upon which this paper is based.

\section{Authors' contributions}

This paper represents a result of collegial teamwork. SP, TY and MG designed the research; SP collected data and conducted analyses; SP prepared the first draft of the manuscript, and; SP, TY and MG jointly finalized the paper. All authors read and approved the final manuscript.

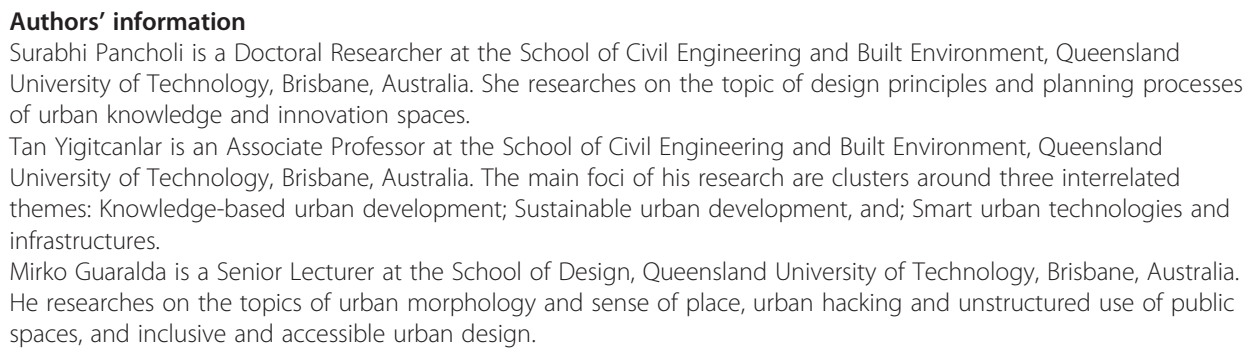


Baum S, O'Connor K, Yigitcanlar T. The implications of creative industries for regional outcomes. Int J Foresight Innov Policy. 2009;5(1):44-64.

Brisbane City Plan. Kelvin Grove Urban Village local plan. Brisbane: Brisbane City Council; 2000.

Buttimer A, Seamon D. The human experience of space and place. London: Croom Helm; 1980.

Carmona M, Heath T, Oc T, Tiesdell S. Public places urban spaces: the dimensions of urban design. London: Architectural Press; 2010.

Carr S, Francis M, Rivlin L, Stone A. Public space. Cambridge: Cambridge University Press; 1992.

Carrillo F. Capital cities: a taxonomy of capital accounts for knowledge cities. J Knowl Manag. 2004;8(5):28-46.

Carrillo F, Yigitcanlar T, Garcia B, Lonnqvist A. Knowledge and the city: concepts, applications and trends of knowledgebased urban development. New York: Routledge; 2014

Charles D. The role of universities in building knowledge cities in Australia. Built Environ. 2011;37(3):281-98.

Chesbrough H. The era of open innovation. MIT Sloan Manag Rev. 2003;44(3):35-41.

Cooke P. Green governance and green clusters: regional \& national policies for the climate change challenge of Central \& Eastern Europe. J Open Inn: Technol, Market Complexity. 2015;1(1):1-17.

Cresswell T. Place: a short introduction. London: Wiley; 2004.

Duff C. On the role of affect and practice in the production of place. Environ Plann D. 2010;28(5):881-95.

Florida R. The economic geography of talent. Ann Assoc Am Geogr. 2002;92(1):743-55.

Florida R. The rise of the creative class: revisited. New York: Basic books; 2012.

Foth $M$, Adkins B. A research design to build effective partnerships between city planners, developers, government and urban neighbourhood communities. J Community Inform. 2006;2(2):116-33.

Foth M, Klaebe H, Hearn G. The role of new media and digital narratives in urban planning and community development. Body, Space Technol. 2008;7(2):1-18.

Inkinen, T. Reflections on the innovative city: examining three innovative locations in a knowledge bases framework. Journal of Open Innovation: Technology, Market, and Complexity. 2015;1(8):1-23.

Kabachanik P. England or Uruguay? The persistence of place and the myth of the placeless Gypsy. Area. 2010;42(2):198-207.

Klaebe H. Sharing stories: a social history of Kelvin Grove Urban Village. Sydney: Focus publishing; 2006.

Klaebe H, Adkins B, Foth M, Hearn G. Embedding an ecology notion in the social production of urban space. In: Foth M, editor. Handbook of Research on Urban Informatics: The Practice and Promise of the Real-Time City. Hershey, PA: IGI Global; 2009. p. 179-94.

Knight R. Knowledge-based development: policy and planning implications for cities. Urban Stud. 1995;32(2):225-60.

Kodama F, Shibata T. Demand articulation in the open-innovation paradigm. J Open Innov: Technol, Market Complexity. 2015;1(2):1-21.

Kunzmann K. The strategic dimensions of knowledge industries in urban development. disP-The Planning Review. 2009;45(177):40-7.

Lippard L. The lure of the local: senses of place in a multicultural society. New York: The New Press; 1997.

Lonnqvist A, Kapyla J, Salonius H, Yigitcanlar T. Knowledge that matters: identifying regional knowledge assets of Tampere Region. Eur Plan Stud. 2014;22(10):2011-29.

Massey D. A global sense of place. Marxism Today. 1991;35(6):24-9.

Massey D. For space. London: Sage; 2005.

Minnery J, Knight J, Byrne J, Spencer J. Bounding neighbourhoods: how do residents do it? Planning Pract Res. 2009;24(4):471-93.

Mort G, Roan A. Smart state: Queensland in the knowledge economy. Qld Rev. 2003;10(1):859-70.

Pancholi S, Yigitcanlar T, Guaralda M. Urban knowledge and innovation spaces: concepts, conditions and contexts. Asia Pac J Innov Entrepreneurship. 2014;8(1):15-38.

Pratt A. Hot jobs in cool places: the material culture of new media product spaces: the case of south of the market, San Francisco. Inf, Commun Soc. 2002;5(1):20-7.

Sabatini-Marques J, Yigitcanlar T, Da Costa E. Incentivizing innovation: a review of the Brazilian federal innovation support programs. Asia Pacific Journal of Innovation and Entrepreneurship. 2015;9(1):31-56.

Shaftoe H. Convivial urban spaces: creating effective public spaces. London: Earthscan; 2008.

Sheppard E. The spaces and times of globalization: place, scale, networks, and positionality. Econ Geogr. 2002;78(3):307-30.

Southworth M, Owens P. The evolving metropolis: studies of community, neighborhood, and street form at the urban edge. J Am Plan Assoc. 1993;59(3):271-87.

Van Winden W. Knowledge and the European city. Econ Soc Geogr. 2010;101(1):100-6.

Watson G, Bentley I. Identity by design. New York: Routledge; 2007.

Wiltshire K. Queensland Smart State: positioning Queensland. Qld Rev. 2003;10(1):1-10.

Worpole K. No particular place to go? Children, young people and public space. London: Groundwork; 2005.

Worpole K, Greenhalgh L. The freedom of the city. London: Demos; 1996.

Yigitcanlar T. Planning for knowledge-based development: global perspectives. J Knowl Manag. 2009;13(5):228-42.

Yigitcanlar T. Making space and place for the knowledge economy: knowledge-based development of Australian cities. Eur Plan Stud. 2010;18(11):1769-86.

Yigitcanlar T. Position paper: benchmarking the performance of global and emerging knowledge cities. Expert Syst Appl. 2014;41(12):5549-59.

Yigitcanlar T, Bulu M. Dubaization of Istanbul: insights from the knowledge-based urban development journey of an emerging local economy. Environ Plann A. 2015;47(1):89-107.

Yigitcanlar T, Dur F. Making space and place for knowledge communities: lessons for Australian practice. Aust J Reg Stud. 2013;19(1):36-63. 
Yigitcanlar T, Lonnqvist A. Benchmarking knowledge-based urban development performance: results from the international comparison of Helsinki. Cities. 2013;31(1):357-69.

Yigitcanlar T, Sarimin M. The role of universities in building prosperous knowledge cities: the Malaysian experience. Built Environ. 2011;37(3):260-80.

Yigitcanlar T, Sarimin M. Multimedia Super Corridor, Malaysia: knowledge-based urban development lessons from an emerging economy. VINE: J Info Knowl Manage. 2015;45(1):126-47.

Yigitcanlar T, Velibeyoglu K. Knowledge-based urban development: the local economic development path of Brisbane, Australia. Local Economy. 2008;23(3):195-207.

Yigitcanlar T, Baum S, Horton S. Attracting and retaining knowledge workers in knowledge cities. J Knowl Manag. 2007:11(5):6-17.

Yigitcanlar T, O'Connor K, Westerman C. The making of knowledge cities: Melbourne's knowledge-based urban development experience. Cities. 2008a;25(2):63-72.

Yigitcanlar T, Velibeyoglu K, Martinez-Fernandez C. Rising knowledge cities: the role of knowledge precincts. J Knowl Manag. 2008b;12(5):8-20.

Yigitcanlar T, Guaralda M, Taboada M, Pancholi S. Place making for knowledge generation and innovation: planning and branding Brisbane's knowledge community precincts. Journal of Urban Technology. 2015b. doi:10.1080/ 10630732.2015 .1090198$.

Yigitcanlar T, Inkinen T, Makkonen T. Does size matter? Knowledge-based development of second-order city-regions in Finland. disP-The Planning Review. 2015a;51(3):153-168.

Zenker S. Who's your target? The creative class as a target group for place branding. J Place Manage Dev. 2009;12(5):8-20.

Zukin S. The cultures of cities. Oxford: Basil Blackwell; 1995.

Submit your manuscript to a SpringerOpen ${ }^{\circ}$ journal and benefit from:

- Convenient online submission

Rigorous peer review

- Immediate publication on acceptance

- Open access: articles freely available online

- High visibility within the field

- Retaining the copyright to your article

Submit your next manuscript at $\gg$ springeropen.com 